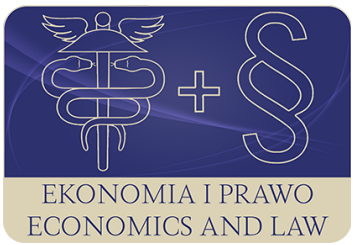

EKONOMIA I PRAWO. ECONOMICS AND LAW

Volume 17, Issue 1, March 2018

p-ISSN 1898-2255, e-ISSN 2392-1625

www.economicsandlaw.pl

ORIGINAL ARTICLE

received 13.06.2017; revised 13.03.2018; accepted 31.03.2018

Citation: Sadowska, B., \& Lulek, A. (2018). The problem of risk in the economy of sustainable

development on the example of the State Forests. Ekonomia i Prawo. Ecomomics and Law, 17(1):

103-120. doi:10.12775/EiP.2018.008.

\title{
The problem of risk in the economy of sustainable development on the example of the State Forests
}

\author{
BEATA SADOWSKA \\ corresponding author \\ University of Szczecin, Faculty of Management and Economics of Services, Department \\ of Accountancy and Controlling, ul. Cukrowa 8, 71-004 Szczecin, Poland \\ $\square$ beata.sadowska@wzieu.pl

\section{ADAM LULEK} \\ University of Szczecin, Faculty of Management and Economics of Services, Department \\ of Accountancy and Controlling, Poland \\ ๑adam-lulek@wp.pl
}

\begin{abstract}
Motivation: Economics of sustainable development aims to ensure standards of environmental, economic and social quality of life and freedom of all people living on Earth. Objectives in all three dimensions should be implemented taking into account their strong interdependence. Targets of sustainable development are implemented, among other things, by the State Forests, i.e. carrying on forest management according to the principles of universal forest protection, durability, their maintenance, continuity and sustainable use of all the functions of forests and expansion of forest resources. Forest management should be carried out while minimizing the economic risk that accompanies each economic activity.
\end{abstract}

Aim: The aim of the study is to identify the risk associated with business operation of State Forests.

Results: The study will also present the risk management process in the State Forests and the characteristics of its individual stages. Identified objective was achieved using a critical analysis of national and international studies, descriptive method and analysis of phenomena and synthesis of results and interviews with foresters. The layout and content of the study was subordinated to the realization of goals. Due to the limited 
article volume, only certain aspects of State Forests were presented, as an area of risk in the economy of sustainable development.

Keywords: risk; sustainable development; economy; forest economy

JEL: Q01; Q23; O13; O44; D81

\section{Introduction}

The concept of sustainable development must be understood as the socio-economic development, in which the process of integration of political, economic and social activities occurs, maintaining environmental balance in order to guarantee the possibility of satisfying the basic needs of the communities both for the present and future generations.

Economics of sustainable development, sustainable development of enterprises (Dellaportas et al., 2005, p. 214) aims to ensure environmental, economic and social standards, quality and freedom of life for all people living on Earth. Priorities for sustainable economic development are carried out by, among others, the State Forests. In accordance with the provisions of the Forest Act (1991), the main task of the State Forests is to conduct forest management according to the principles of universal forest protection, durability, their maintenance, continuity and sustainable use of all the functions of forests and expansion of forest resources. Forest management should be carried out while minimizing the economic risk that accompanies each activity.

The aim of the study is to identify the risk associated with business operation of the State Forests. There was an attempt to verify the hypothesis that the identification of risks at various levels of functioning of the State Forests business is the first step to manage risk ${ }^{1}$. The study also presents the risk management process in the State Forests and the characteristics of its individual stages.

\section{Literature review}

The concept of development is defined differently. The most common development is defined as a long process of directional changes, in which it is possible to correct the following stages of change of the object. The sustainable and balanced development is considered as social and economic development, ensuring to meet the needs of modern societies, without prejudice to the possibility of meeting the needs of future generations. Sustainable development (Sadowska, 2017, p. 139) refers to the holistic approach and temporal processes that lead us to the point of sustainability (Shaker, 2015, pp. 304-314). Sustainable development also refers to economic processes in the socio-ecological context, with emphasis on links between the man and the nature, and the in-

${ }^{1}$ Risk management can also be described as broad management activities which task is to identify and evaluate risks and the fight against its causes and impact on the organization. It is also described as identification, measurement, control and management of the risk to minimize and protect against its consequences. 
dividual voices of people calling for moderation appeared in antiquity - they were related to programs of afforestation and felling. Already in the sixteenth century, it was written in the forest code of Rhineland - Palatinate that you were permitted cut down only as many trees as it may grow, so that there would be enough wood for posterity. This way the demand for ecological capital was justified (Luks, 2002, p. 20).

Origins of the concept assumptions of sustainable development is seen in the decision of the Austrian officer of the Saxony Kingdom, Hans Carl von Carlowitz, who in 1713 introduced the principle of raising the amount of feudal wood, so that it was possible to recover it during the year. This method of farming was necessary then because industrial investments began to threaten the life of Polish forests. The starting point for the discussion on sustainable development was the statement in the seventies and eighties, that a person poses a threat to the foundations of their existence through excessive exploitation of natural resources. To address concerns over impacts of expanding human development on Earth, E. Barbier (1987, pp. 101-110) published the study titled The concept of sustainable economic development, where he recognised that goals of environmental conservation and economic development are not conflicting and can reinforce each other. Another study, Interpreting sustainability in economic terms, found three pillars of sustainable development: interlinkage, intergenerational equity, and dynamic efficiency (Stavins et al., 2003, pp. 339-343).

It should be emphasized that the principle of sustainable development was recognized in Article 5 of the Constitution of the Republic of Poland (1997), which stipulates that 'The Republic of Poland (...) provides protection of the environment, guided by the principle of sustainable development'. Economics of sustainable development aims to ensure environmental, economic and social standards (scheme 1), quality of life and freedom of all people living on Earth. Goals in all three dimensions should be implemented taking into account their strong interdependence.

Within each of the three dimensions of the concept of sustainable development, it is possible to determine a number of targets faced by the modern economy (Roggal, 2010, p. 47), as shown in scheme 2 . The objectives of sustainable economic development are carried out by, among others the State Forests. In accordance with the provisions of the Forest Act (1991), the main task of the State Forests is to conduct forest management according to the following principles:

- universal forest protection and sustainability of their maintenance;

- continuity and sustainable use of all forest functions;

- expansion of forest resources.

Forest management is conducted in a sustainable way according to the legal document, which is a 'management plan' (Ważyński, 2014, p. 59) that includes a description and assessment of the forest and the objectives, tasks and methods of forest management. The performance of the basic functions on the forest 
farm condition determines: the legal status of organizational units and natural - economic production conditions.

The Forest Act (1991) in Article 13 indicates that in order to implement sustainable forest management the State Forests is obliged to:

- initiate, coordinate and conduct periodic assessment of forests and forest resources;

- forecast changes in forest ecosystems;

- prepare an inventory of forests multiarea;

- keep the database of feudal resource and state of forests.

With this in mind, there are three basic functions of the forest: ecological, social and economic, as shown in table 1.

It should be emphasized that the main function of the forest was historically indicated as the production of wood, and forest was seen only as an economic good. Forestry farm as a multifunctional farm is a place of work, shaping the climate and water conditions; provides a product, such as wood; is a place of rest for people. In terms of multifunctionality, it has no counterpart among other industry holdings.

Forestry is related to silviculture, forest protection, forest utilization, maintenance and enhancement of forest resources, management of the hunted animals, raising undergrowth crops, trees or medicinal plants. Through fulfilling the ecological, social and economic functions, forest management responds to the specific needs reported by the public. Forest is the source of many utilities, and according to the paradigm that the forest should last forever, risks associated with conducting sustainable forest management should be taken into account, according to the concept of sustainable development.

The risk accompanies all processes implemented in the economic entity. In theoretical terms, the risk is 'uncertainty associated with an event or action that will affect the organization's ability to achieve the objectives of its business'. It is also the possibility of an event occurring that will have an impact on the performance of the goals by an entity. It is also associated as a consequence of actions taken in spite of uncertainty (Antunes \& Gonzalez, 2015, pp. 209-228). A special dimension of risk occurs in the State Forests, as shown in scheme 3.

In its daily activities, the State Forests are exposed to the presence of diverse types of risk, which primary classification is shown in table 2 .

In conclusion, attention should be paid to the possible consequences of risk related to the ecological, social and economic functions, such as:

- disturbance of stability and diversity of plants and animals;

- high costs of protection of soil and water resources;

- disturbances of water outflow regulation;

- disturbance of the natural resistance of forests, and thus disturbances in the durability of the forest;

- high costs of monitoring hazards (harmful biotic factors);

- increase in the number of agrotropic sprays; 
- increase in the number of various emergency procedures, including insecticides and fungicides;

- significant expenditures for the protection of crops and young people against animals;

- damage to forest vegetation and soil when tourists visit the forest, which entails the involvement of additional resources necessary for care and repair;

- littering the forest (high cleaning costs);

- noise problem in the aspect of forest game, stress factors and attempts to eliminate them;

- pollution of the environment with fumes or other substances (expenditure on cleaning);

- reducing the possibility of annual timber harvesting (grub) from the forests of all properties;

- reduction in the size of binding and accumulation of carbon dioxide;

- reduction of forest retention properties and mitigation of water deficit in the country and in forest ecosystems.

The State Forests, while doing business, face threats that will not reach their goals. The causes of risk are determined by external factors, i.e. the environment or the political aspects as well as internal factors, i.e. the management of the organization and human capital.

Risk in business activity of the State Forests appears frequently. It is difficult to predict its strength and direction. The State Forests has to skilfully manage risk, that is, take care of it, to fulfil the ecological, social and economic functions of forests, mitigate obstacles which hinder implementation of the objectives and tasks of the State Forests. In order to minimize the negative effects of the various risks in the business practice, a large number of complex actions in the risk management system are being used.

The issue of the occurrence of risk in the State Forests is of interest to many authors, including: Bruchwald \& Dmyterko (2011, pp. 459-471); Hilszczański \& Starzyk (2017, pp. 88-92); Mrówka (2015, pp. 460-475); Niemczyk (2015, pp. 326-335); Paluch (2012, pp. 326-337); Szczygieł et al. (2009, pp. 131141); Wilpert (2015, pp. 37-44).

\section{Methods}

Identified objective was achieved using a critical analysis of national and international studies, descriptive method, comparative methods and analysis of phenomena and synthesis of results and interviews with foresters. Interviews were conducted with randomly selected foresters, mainly employed in forestry offices in the Zachodniopomorskie and Lubuskie voivodships, between October 2016 and March 2017 and during the forest conference held in Kołobrzeg in 2016. The purpose of the interviews was a general diagnosis of the problem. The layout and content of the study was subordinated to the accomplishment of the goals. The task of the research process was to identify the research prob- 
lem, i.e. identify risk associated with business operation of the State Forests. During the study, the risk in State Forests was assessed and it was indicated how to mitigate the risk. The final stage of testing referred to the problem. Conclusions were drawn on that basis. Due to the limited article volume, only certain aspects of the State Forests were presented, as an area of risk in the economy of sustainable development.

\section{Results}

The risk management process in the State Forests can be formal or informal, it can be integrated in the activities of each forest district or controlled centrally. The subject of risk management is to identify risks and take appropriate actions. It is also defined as identification, assessment, and prioritization of risks followed by coordinated and economical application of resources to minimize, monitor, and control the probability and impact of unfortunate events (Hubbard, 2009, p. 46). When analysing the risk of individual areas of the State Forests, it is important to indicate the risk factors of the area and assess their impact on key business elements or to create the hierarchy of risk. The risk management process is shown in scheme 4 .

The internal and external risk should be evaluated and responded to. It is possible to tolerate it, transfer it or withdraw from the action. One of the major constituents of successful risk control is the use of risk response (Baker et al., 1999, pp. 205-213). The literature identifies four types of risk response, as shown in scheme 5 .

Once risk has been identified and assessed, an authorized person decides which of the above actions should be implemented in a specific situation of risk. The risk management process consists of several steps, as shown in scheme 6 .

Referring to table 2, which lists some elements of the diverse types of risk in the State Forests (table 3), there was an attempt to assess the impact of risk on the State Forests, the probability and significance of risk. A list of measures aimed at mitigating the risk was proposed ${ }^{2}$.

Risk management in the State Forests is the systematic application of strategies (rules, regulations), management in all areas and types of activity of the company. Elements of risk are rooted in every action. They need to be effectively managed, which could minimize the level of risk. Different activities may reduce risk (Miller \& Chen, 2003, p. 373). Among other methods of reducing the level of risk, it is possible to include:

- creation of reserves;

2 The authors focused in this paper on general risk issues in State Forests due to the limited volume of the article and a broad approach to this problem both by the scientific community and practitioners. This issue, which will be extremely important, will be the subject of further publications by the authors. The authors hope that this voice in the discussion may be a contribution to the development of new methods for risk assessment and risk prevention. 
- insurance;

- ratio analysis;

- introduction of a system of internal control;

- proper selection of business partners;

- concluding long-term agreements, proven in legal terms;

- SWOT analysis.

Risk management in the State Forests requires the fulfilment of certain conditions, i.e. all employees should properly identify and assess risk and identify tools and methods to mitigate risk. Employees of the State Forests should also be aware of the benefits of risk management. The sooner risks are identified, the faster plans can be made to mitigate or manage them (National Research Council, 2005, p. 22). Risk management should be an integral part of the overall management process in the State Forests. Risk management faces many difficulties in practice, i.e.:

- the risk management process is complex, and the abnormal structure of the organization of risk management can lead to inefficiencies in terms of risk identification;

- subjectivity in the approach to risk classification of different risks and different weights of individual risks;

- the danger of a lack of proper risk assessment in the initial phase of implementation of risk management, inadequate regulatory action;

- lack of communication and acceptance of risk management procedures (different objectives and interest groups).

Due to the changing reality of risk management, it is not possible to encompass it in the specific rules of conduct that would be optimal in every situation that occurs in the activities of the State Forests. Therefore, it is very important that the process of risk management is observed by a designated employee or team of people who, with their knowledge, insight and experience will be able to effectively manage risk and minimize it.

\section{Conclusions}

The State Forest is the largest organization in the European Union managing forests belonging to the State Treasury. As the first director of the State Forests, Adam Loret, a great authority among foresters, wrote: 'The importance of forestry is not limited to the economic life of the nation. Forest still has many irreplaceable properties for the country, to mention only the impact of its climate, humidity and soil protection, health, etc.' (Lasy Państwowe, 2014).

Due to the ecological, social and economic functions, which the State Forests performs in the economy of sustainable development, special attention should be paid to the risks of the company's business and the aspect of limitation. The risk in forest management was the basis for considerations of this study, and the purpose of the study was to identify the risk associated with the business operations of the State Forests and to attempt to verify the hypothesis that the identification 
of risks at various levels of functioning of the State Forests business is the first step in risk management, including risk mitigation. The study shows the risk management process in the State Forests and the characteristics of its individual stages. This iterative research process, based both on literature studies - Polish and foreign, descriptive method, analysis and synthesis of phenomena results and interviews with foresters, enabled the accomplishment of the objective. The study and detailed analysis allowed to define the following conclusions:

- sustainable development refers to economic processes in the socio-ecological context, with emphasis on links between the man and the nature;

- management objectives of sustainable development are achieved among others by the State Forests, i.e. led by sustainable forest management;

- farm forestry as multifunctional business is a place of work, shaping the climate and water conditions, provides a product, such as wood and is a place where people can rest;

- risk accompanies all processes carried out by economic entities, including activities carried out by the State Forests;

- the best example of how important it is to assess and manage risk is issues of nature conservation in the Bialowieza Forest and contemporary problems of the State Forests related to this issue;

- the State Forests in their daily activity are exposed to the presence of diverse types of risks (e.g. environmental, legal, political, related to the management of the organization and human capital risk);

- State Forests must skilfully manage risk, that is, take care of it, to fulfil the ecological, social and economic functions of forests, mitigate obstacles which hinder the implementation of the objectives and tasks of the State Forests;

- by creating a risk register, the State Forests can estimate the level of risk, assess the impact of risk on a given area of activity, assess the probability of the risk and determine the methods of counteracting the risk or manage risk.

\section{References}

Antunes, R., \& Gonzalez, V. (2015). A production model for construction: a theoretical framework. Buildings, 5(1). doi:10.3390/buildings5010209.

Baker, S., Ponniah, D., \& Smith, S. (1999). Risk response techniques employed currently for major projects. Construction Management and Economics, 17(2). doi:10.1080/014461999371709.

Barbier, E. (1987). The concept of sustainable economic development. Environmental Conservation, 14(2). doi:10.1017/S0376892900011449.

Bruchwald, A., \& Dmyterko, E. (2011). Zastosowanie modeli ryzyka uszkodzenia drzewostanu przez wiatr do oceny zagrożenia lasów nadleśnictwa. Sylwan, 155(7). 
Dellaportas, S., Gibson, K., Alagiah, R., Hutchinson, M., Leung, P., \& van Homrigh, D. (2005). Ethics, governance and accountability. Brisbane: Wiley \& Sons.

Hilszczański, J., \& Starzyk, J.R. (2017). Czy ograniczanie gradacji kornika drukarza Ips typographus (L.) w Puszczy Białowieskiej jest możliwe i potrzebne? Leśne Prace Badawcze, 78 (1).

Hubbard, W.D. (2009). The failure of risk management: why it's broken and how to fix it. Hoboken: Wiley \& Sons. doi:10.1002/9781119198536.

Konstytucja Rzeczypospolitej Polskiej z dnia 2 kwietnia 1997 r. [Constitution of the Republic of Poland of 2 April 1997] (Dz.U. 1997 nr 78 poz. 483) (Poland).

Lasy Państwowe. (2013). Strategia Państwowego Gospodarstwa Leśnego Lasy Państwowe na lata 2014-2030. Retrieved 23.08.2015 from http://zlpwrp.pl.

Lasy Państwowe. (2014). Misja. Retrieved 23.08.2015 from https://www.lasy. gov.pl.

Luks, F. (2002). Nachhaltigkeit. Hamburg: Europäische Verlagsanstalt.

Miller, K.D., \& Chen, W. (2003). Risk and firm's costs. Strategic Organization, 1(4). doi:10.1177/14761270030014001.

Mrówka, J. (2015). Wdrożenie strategii - czynniki i obszary ryzyka na przykładzie PGL Lasy Państwowe, Marketing i Rynek, 5.

National Research Council. (2005). The owner's role in project risk management, Washington: The National Academies Press. doi:10.17226/11183.

Niemczyk, M. (2015). Ryzyko masowego występowania pędraków chrabąszczy (Melolontha spp.) w strefie ekotonowej drzewostanów dojrzałych na terenie Nadleśnictwa Lubaczów. Sylwan, 159(4).

Paluch, R. (2012). Bierna ochrona przyrody w puszczy białowieskiej — jej skuteczność i konsekwencje. Zarządzanie Ochroną Przyrody w Lasach, 06.

Roggal, H. (2010). Ekonomia zrównoważonego rozwoju. Poznań: Zysk i S-ka.

Sadowska, B. (2017). Rola rachunkowości we wspieraniu zrównoważonego rozwoju na przykładzie państwowego Gospodarstwa Leśnego Lasy Państwowe. Prace Naukowe Uniwersytetu Ekonomicznego we Wroctawiu, 479. doi:10.15611/ pn.2017.479.12.

Shaker, R.R. (2015). The spatial distribution of development in Europe and its underlying sustainability correlations. Applied Geography, 63. doi:10.1016/j. apgeog.2015.07.009.

Stavins, R., Wagner, A., \& Wagner, G. (2003). Interpreting sustainability in economic terms: dynamic efficiency plus intergenerational equity. Economic Letters, 79(3). doi:10.1016/s0165-1765(03)00036-3.

Szczygiet, R., Ubysz, B., Kwiatkowski, M., \& Piwnicki, J. (2009). Klasyfikacja zagrożenia pożarowego lasów Polski. Leśne Prace Badawcze, 70(2).

Ustawa z dnia 28 września 1991 r. o lasach [Forest Act of 28 September 1991] (Dz.U. $1991 \mathrm{nr} 101$ poz. 444) (Poland).

Ważyński, B. (2014). Gospodarka leśna. In B. Ważyński (Ed.), Podstawy gospodarki leśnej. Poznań: UP w Poznaniu. 
Wilpert, K. (2015). Zarządzanie ryzykiem w leśnictwie XXI wieku. In Z. Sierota (Ed.), Wyzwania i szanse leśnictwa XXI wieku. Sękocin Stary: Instytut Badawczy Leśnictwa.

\section{Acknowledgements}

Author contributions: authors have given an approval to the final version of the article. Authors contributed to this work equally.

Funding: this research was fully funded by the University of Szczecin.

Note: the results of this study were presented at 9th International Conference on Applied Economics Contemporary Issues in Economy (June 22-23, Toruń, Poland). 


\section{Appendix}

Table 1.

Basic functions of forest

\begin{tabular}{|c|c|c|}
\hline Ecological functions & Social functions & Economic functions \\
\hline $\begin{array}{l}\text { - conservations of plant and animal } \\
\text { resources, their stability and di- } \\
\text { versity; } \\
\text { - } \mathrm{CO}_{2} \text { reduction; } \\
\text { - conservation of soil and water; } \\
\text { - regulation of water runoff. }\end{array}$ & $\begin{array}{l}\text { - contact with nature; } \\
\text { - spending free time in the woods, } \\
\text { a place of recreation; } \\
\text { - practising sport and bringing } \\
\text { tourism to the forest; } \\
\text { - providing forest products for daily } \\
\text { needs (mushrooms, resin, forest } \\
\text { fruit). }\end{array}$ & $\begin{array}{l}\text { - providing wood as raw material } \\
\text { for industry and consumption; } \\
\text { - developing labor market within } \\
\text { the local community; } \\
\text { - producing medicine. }\end{array}$ \\
\hline
\end{tabular}

Source: Own preparation based on Lasy Państwowe (2013). 
Table 2.

Diverse types of risk in the State Forests

\begin{tabular}{|c|c|c|c|}
\hline No. & Area of risk & Category of risk & Characteristics \\
\hline 1. & environment & business risk & $\begin{array}{l}\text { - the negative impact of biotic and abiotic factors on the stability } \\
\text { of forests; } \\
\text { - the negative impact of anthropogenic factors on the stability of for- } \\
\text { ests; } \\
\text { - low and very high temperatures; } \\
\text { - lightings; } \\
\text { - hail and avalanches; } \\
\text { - urbanization, mining; } \\
\text { - communication; } \\
\text { - forest fires and wrecking; } \\
\text { - the impact of recreation on forests; } \\
\text { - plant diseases. }\end{array}$ \\
\hline 2. & policy and law & $\begin{array}{l}\text { business risk, } \\
\text { financial risk }\end{array}$ & $\begin{array}{l}\text { - the possibility of privatisation of forest resources; } \\
\text { - variability and inconsistency of the law; } \\
\text { - the possibility of introducing additional taxes related to the activities } \\
\text { of the State Forests; } \\
\text { - introduction of solutions without analysing their effects; } \\
\text { - the tenure of authorities; } \\
\text { - inefficient decisions under pressure from the lobby; } \\
\text { - the State Forests is obliged to reorganize their structures and meth- } \\
\text { ods of operation due to frequent legal changes. }\end{array}$ \\
\hline 3. & society & business risk & $\begin{array}{l}\text { - increased, uncontrolled tourism; } \\
\text { - polarization of social acceptance for the activities of the State For- } \\
\text { ests; } \\
\text { - the lack of social acceptance for the activities of the State Forests; } \\
\text { - risk associated with the temptation to abuse; } \\
\text { - destruction of forest resources and forest undergrowth; } \\
\text { - theft of wood; } \\
\text { - forest pollution. }\end{array}$ \\
\hline 4. & forest business & $\begin{array}{l}\text { business risk, } \\
\text { financial risk }\end{array}$ & $\begin{array}{l}\text { - fragmentation of forest entrepreneurs; } \\
\text { - quality of service appropriate to the applicable criteria, the lowest } \\
\text { prices in public tenders; } \\
\text { - lack of a training system and certification of qualifications of forest } \\
\text { service providers; } \\
\text { - poor service; } \\
\text { - lack of service automation; } \\
\text { - low-skilled staff among providers of forestry services. }\end{array}$ \\
\hline 5. & $\begin{array}{l}\text { customers } \\
\text { and competitors }\end{array}$ & business risk & $\begin{array}{l}\text { - fluctuations in market demand; } \\
\text { - outflow of capital from the timber industry to other countries; } \\
\text { - import of cheap wood; } \\
\text { - regulations restricting the use of wood. }\end{array}$ \\
\hline
\end{tabular}




\begin{tabular}{|c|c|c|c|}
\hline No. & Area of risk & Category of risk & Characteristics \\
\hline 6. & $\begin{array}{c}\text { local } \\
\text { governments }\end{array}$ & $\begin{array}{l}\text { business risk, } \\
\text { financial risk }\end{array}$ & $\begin{array}{l}\text { - poor quality of road infrastructure; } \\
\text { - expectations of local governments to the State Forests with regards } \\
\text { to local taxes; } \\
\text { - lack of government initiatives for the protection of forests; } \\
\text { - limited access to the forests; } \\
\text { - } \text { risk of excessive fiscalism. }\end{array}$ \\
\hline 7. & $\begin{array}{l}\text { non- } \\
\text { governmental } \\
\text { organizations }\end{array}$ & business risk & $\begin{array}{l}\text { - measures aimed at the protection of nature at any cost; } \\
\text { - making it difficult to conduct forest management; } \\
\text { - conflicts. }\end{array}$ \\
\hline 8. & $\begin{array}{c}\text { internal } \\
\text { management }\end{array}$ & $\begin{array}{l}\text { business risk, } \\
\text { financial risk }\end{array}$ & $\begin{array}{l}\text { - management efficiency; } \\
\text { - access to information; } \\
\text { - communication; } \\
\text { - process optimization; } \\
\text { - focus on current operations; } \\
\text { - accounting; } \\
\text { - vague and non-transparent procedures and acts of law; } \\
\text { - loss of data processed in information systems; } \\
\text { - disclosure of passwords to unauthorized people; } \\
\text { - bookkeeping only on the basis of mandatory provisions of law; } \\
\text { - lack of modern tools of management accounting and controlling; } \\
\text { - exceeding the expenditure plan; } \\
\text { - risk of corruption. }\end{array}$ \\
\hline 9. & human capital & $\begin{array}{l}\text { human } \\
\text { resources risk }\end{array}$ & $\begin{array}{l}\text { - staff negligence and fraud; } \\
\text { - motivation systems; } \\
\text { - training system; } \\
\text { - internal regulations and laws; } \\
\text { - inadequate personnel policy; } \\
\text { - a large number of employees; } \\
\text { - accountability system; } \\
\text { - the lack of clear criteria for the distribution of responsibility at low - } \\
\text { er levels of the organizational structure; } \\
\text { - inadequate procedures for motivating employees; } \\
\text { - wrong system of work delegation; } \\
\text { - lack of coherent communication. }\end{array}$ \\
\hline
\end{tabular}

Source: Own preparation based on Lasy Państwowe (2013). 
Table 3.

Risk assessment in the State Forests and risk prevention — risk registration

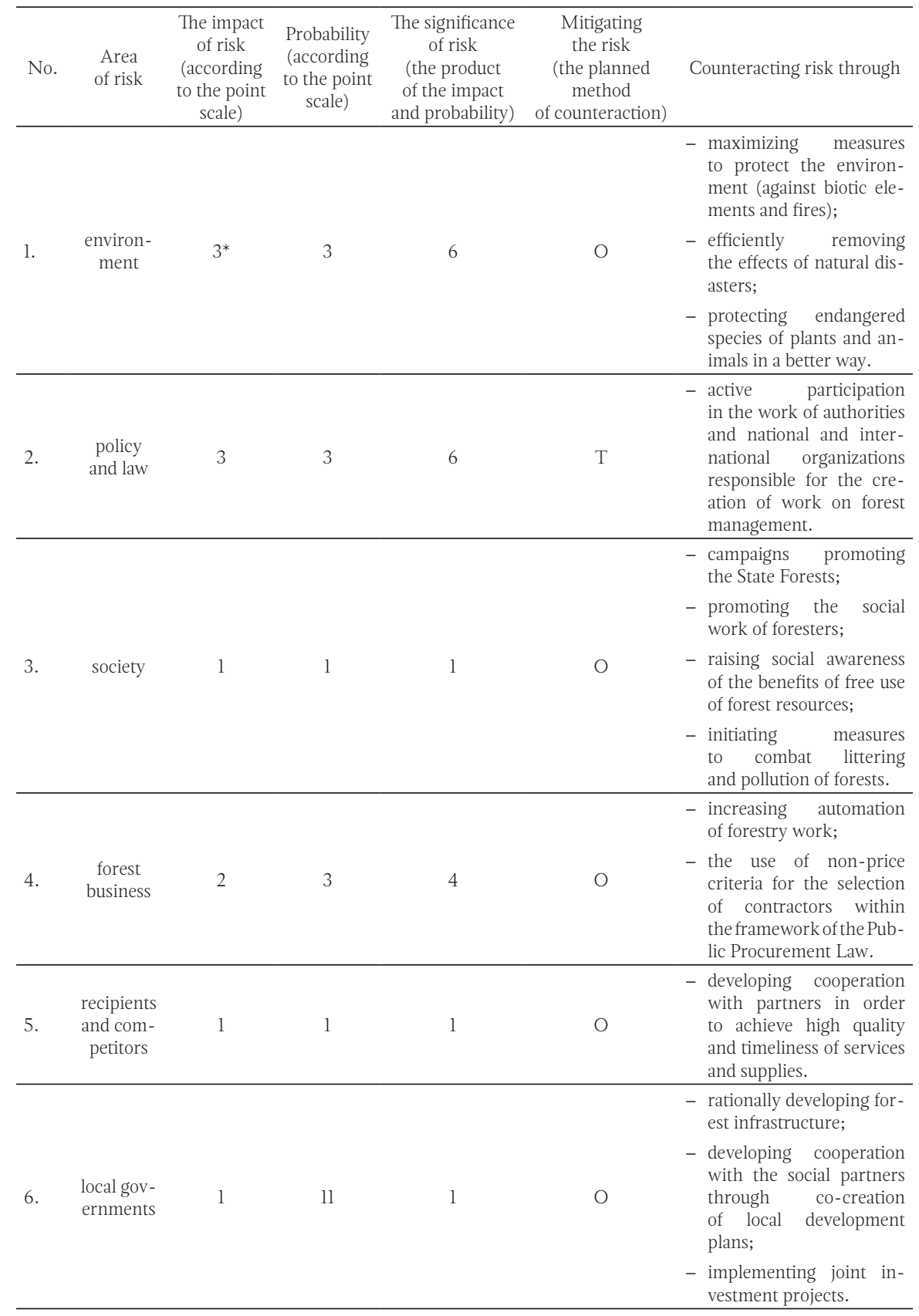




\begin{tabular}{|c|c|c|c|c|c|c|}
\hline No. & $\begin{array}{l}\text { Area } \\
\text { of risk }\end{array}$ & $\begin{array}{l}\text { The impact } \\
\text { of risk } \\
\text { (according } \\
\text { to the point } \\
\text { scale) }\end{array}$ & $\begin{array}{c}\text { Probability } \\
\text { (according } \\
\text { to the point } \\
\text { scale) }\end{array}$ & $\begin{array}{c}\text { The significance } \\
\text { of risk } \\
\text { (the product } \\
\text { of the impact } \\
\text { and probability) }\end{array}$ & $\begin{array}{c}\text { Mitigating } \\
\text { the risk } \\
\text { (the planned } \\
\text { method } \\
\text { of counteraction) }\end{array}$ & Counteracting risk through \\
\hline 7. & $\begin{array}{l}\text { non-gov- } \\
\text { ernmental } \\
\text { organiza- } \\
\text { tions }\end{array}$ & 2 & 2 & 4 & $\mathrm{~T}$ & $\begin{array}{l}\text { - cooperation with bodies } \\
\text { and organizations to be } \\
\text { appointed to the conser- } \\
\text { vation and implemen- } \\
\text { tation of joint projects } \\
\text { and initiatives. }\end{array}$ \\
\hline 8. & $\begin{array}{l}\text { internal } \\
\text { manage- } \\
\text { ment }\end{array}$ & 2 & 1 & 4 & $\mathrm{P}$ & $\begin{array}{l}\text { - i m p l e m e nt a t i o n } \\
\text { of research results } \\
\text { and innovative solu- } \\
\text { tions in the management } \\
\text { of the organization; } \\
\text { - exploration and use of ad- } \\
\text { ditional sources of rev- } \\
\text { enue; } \\
\text { - reduction of operating } \\
\text { costs; } \\
\text { - the use of accounting } \\
\text { and controlling tools, } \\
\text { for example: Balanced } \\
\text { Scorecard or time-based } \\
\text { costing. }\end{array}$ \\
\hline 9. & $\begin{array}{l}\text { human } \\
\text { capital }\end{array}$ & 2 & 3 & 4 & $\mathrm{P}$ & $\begin{array}{l}\text { - new jobs creation; } \\
\text { - efficient management } \\
\text { of human capital as } \\
\text { a result of internal regu- } \\
\text { lations (rules for the bo- } \\
\text { nus, motivation, training, } \\
\text { employee replacement); } \\
\text { - staff training (including } \\
\text { cascading ones); } \\
\text { - knowledge sharing, rais- } \\
\text { ing employees' qualifica- } \\
\text { tions. }\end{array}$ \\
\hline
\end{tabular}

Note:

A subjective assessment of the impact of risk, probability of its occurrence and significance of risk in the range from 0 to 9 was adopted.

Impact assessment scale: high -3 points, average -2 points, low -1 point.

Probability assessment scale: high -3 points, average -2 points, low -1 point.

The risk significance level resulting from granted ratings of probability and impact according to the scale: serious risk -6 to 9 points, moderate risk -3 to 4 points, slight risk -1 to 2 points.

Indication of planned methods to counteract risk. The planned method of counteracting the risk: $\mathrm{O}-$ control and reduction, $\mathrm{P}$ - transfer of responsibility, $\mathrm{T}$ - risk tolerance.

Source: Own preparation based on Lasy Państwowe (2013). 


\section{Scheme 1 .}

The dimensions of objectives of sustainable development economy

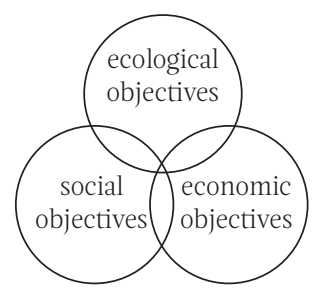

Source: Own preparation.

\section{Scheme 2.}

Objectives of sustainable economic development

\begin{tabular}{|c|c|}
\hline $\begin{array}{l}\text { ecological } \\
\text { objectives }\end{array}$ & $\begin{array}{l}\text { - protection of Earth's atmosphere; } \\
\text { - preservation of natural diversity; } \\
\text { - sustainalbe use of renewable and non-renewable resources; } \\
\text { - elimination of harmful substances. }\end{array}$ \\
\hline $\begin{array}{l}\text { economic } \\
\text { objectives }\end{array}$ & $\begin{array}{l}\text { - the stability of the national economy; } \\
\text { - meeting the basic needs of society; } \\
\text { - price stability; } \\
\text { - non-economic balance and development cooperation; } \\
\text { - efficient state budget. }\end{array}$ \\
\hline $\begin{array}{c}\text { social } \\
\text { objectives }\end{array}$ & $\begin{array}{l}\text { - participatory democracy and the rule of law; } \\
\text { - poverty eradication, social security; } \\
\text { - equal opportunities and social integration; } \\
\text { - internal and external security of people's lives. }\end{array}$ \\
\hline
\end{tabular}

Source: Own preparation based on Roggal (2010, p. 47). 
Scheme 3.

Special dimension of risk in the State Forests

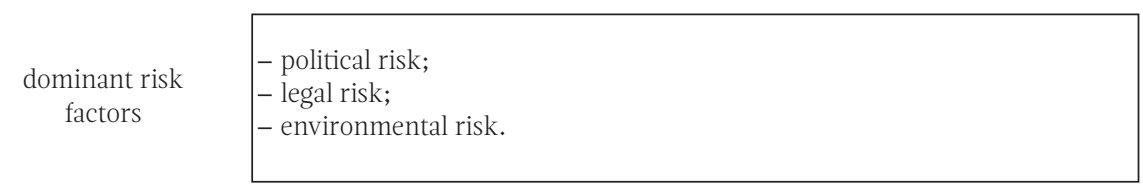

\begin{tabular}{c|l|} 
& - outdated management methods; \\
main factors & - politicisation; \\
determining risk & - information asymmetry; \\
& - rigid policies; \\
- 'fuzzy responsibility'; \\
- lack of modern accounting methods.
\end{tabular}

\begin{tabular}{c|l|}
$\begin{array}{c}\text { factors lowering the } \\
\text { possibility of risk } \\
\text { management }\end{array}$ & - lobbying; \\
& - limited awareness of the need for a change; \\
& - the resistance of managers and employees before implementing changes; \\
&
\end{tabular}

Source: Own preparation.

\section{Scheme 4.}

\section{Risk management process}

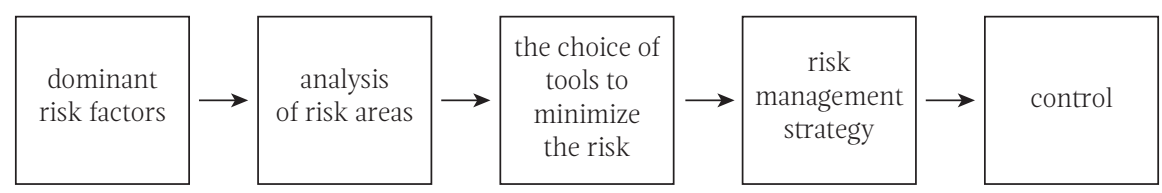

Source: Own preparation.

\section{Scheme 5.}

\section{Risk response}

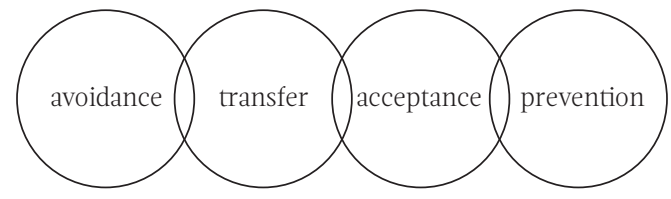

Source: Own preparation. 


\section{Scheme 6 .}

\section{Risk management steps}

\begin{tabular}{c|l|}
\hline defining objectives & $\begin{array}{l}- \text { risk management objectives need to coordinate the tasks of the } \\
\text { organization. }\end{array}$ \\
$\qquad \begin{array}{l}- \text { risk identification is the process of systematic and continuous detection of } \\
\text { risks that can be found in the organization; } \\
\text { - risk analysis refers to factors that cause risks and indicates how they } \\
\text { affect the occurance of losses; } \\
\text { risk evaluation } \\
\text { me measurement of risk (it requires the risk manager to determine the } \\
\text { measure to the identified risk types). }\end{array}$ \\
risk control & $\begin{array}{l}- \text { risk control includes methods aimed at better understanding activities in } \\
\text { the organization affecting the pontential risk. Effective control reduces } \\
\text { the exposure to risk in an organization. }\end{array}$ \\
financing risk & $\begin{array}{l}- \text { provides means for securing the resulting losses and financing programs } \\
\text { aimed at reducing risk. }\end{array}$ \\
\hline
\end{tabular}

Source: Own preparation. 